TITLE:

\title{
Blockade of CXCL12/CXCR4 axis ameliorates murine experimental colitis(Abstract_要旨)
}

$\operatorname{AUTHOR}(\mathrm{S})$ :

Mikami, Sakae

\section{CITATION:}

Mikami, Sakae. Blockade of CXCL12/CXCR4 axis ameliorates murine experimental colitis. 京都大学, 2009, 博士(医学)

ISSUE DATE:

2009-01-23

URL:

http://hdl.handle.net/2433/124258

RIGHT: 


\begin{tabular}{|c|c|c|}
\hline 京都大学 & 博士 (医学) & 氏 名 三上 栄 \\
\hline 論文題目 & \multicolumn{2}{|c|}{$\begin{array}{l}\text { Blockade of CXCL12/CXCR4 axis ameliorates murine experimental colitis } \\
\text { (CXCL12/CXCR4 シグナルの阻害によりマウス腸炎は軽減する) }\end{array}$} \\
\hline \multicolumn{3}{|c|}{ 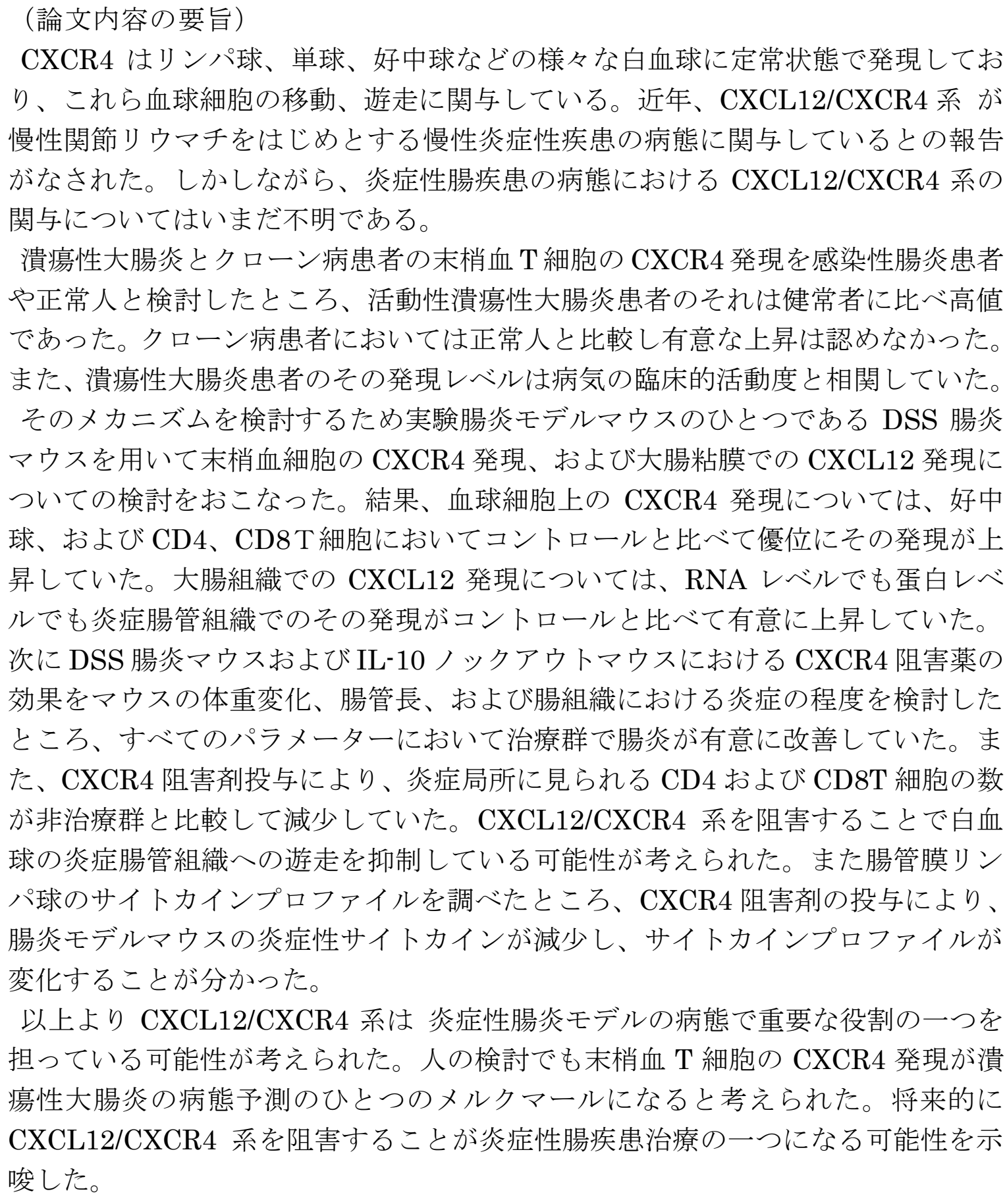 } \\
\hline
\end{tabular}

（論文審査の結果の要旨）

CXCR4 は様々な白血球に定常状態で発現しており、これら血球細胞の移動、遊走に 関与している。近年 CXCL12/CXCR4 系が関節リウマチなどの慢性炎症性疾患の病態 一の関与の報告がされているが、炎症性腸疾患に於いてはその関与が不明であった。 今回、申請者はヒト、及びマウス腸炎における CXCL12/CXCR4 系の関与について検 討をおこなった。

人の検討では、活動性潰瘍性大腸炎患者の未梢血 $\mathrm{T}$ 細胞の CXCR4 発現は健常者に比 べ高值であった。また、潰瘍性大腸炎患者の CXCR4 発現レベルは臨床的活動度と相 関していたことより、CXCL12/CXCR4 系が潰瘍性大腸炎の病態に関わっている可能 性、さらにその発現の程度および変化が潰瘍性大腸炎の病態予測のひとつの指標にな る可能性が考えられた。そのメカニズムの解明のため実験腸炎モデルマウスのひとつ である DSS 腸炎マウスを用いて未梢血細胞の CXCR4 発現、及び大腸粘膜での CXCL12 発現の検討をおこなった。結果・好中球・T 細胞上の CXCR4 発現、および 大腸組織での CXCL12 発現が炎症により優位に上昇していた。これよりこの腸炎モデ ルにおいてもCXCL12/CXCR4系の関与が強く示唆された。DSS 腸炎マウス及びIL-10 K/O マウスでの CXCR4 阻害薬による治療効果の検討では、阻害薬投与により炎症局 所に認める $\mathrm{T}$ 細胞の数が非治療群と比較して減少していた。腸管膜リンパ球が産生寸 る炎症性サイトカインも、CXCR4 阻害剤の投与により減少することが示された。また、 組織学的にも治療群で腸炎が有意に改善した。以上より CXCL12/CXCR4 系の阻害薬 が治療薬のひとつになりうる可能性が示唆された

以上の研究は、炎症性腸疾患の機序の解明に貢献し、その診断、治療、さらに治療効 果の判定に寄与寸るところが多い。したがって本論文は博士(医学)の学位論文として価 值あるものと認める。なお、本学位授与甲請者は、平成 20 年 12 月 24 日実施の論文内 容とそれに関連した諮問を受け、合格と認められたものである。 